\title{
An examination of international accounting standard-setting due process and the implications for legitimacy
}

\section{Abstract}

This paper explores the due process of accounting standard-setting by focusing on relative levels of stakeholder and jurisdictional influence. We draw on legitimacy theory to explain our findings and ask what implications any bias might have for the IASB. This study extends the standard-setting literature in three ways. First, we create a weighted coding system to analyse the content of comment letters. Second, we test for differences in the acceptance rate of comments made by stakeholders and by jurisdictions. Third, we analyse IASB discussion documentation that sheds light on the decision-making process. Previous studies have focused on whether outcome-oriented proposals are 'influential' (persuasive) by focusing on success rates measured as proposed changes being accepted. We widen this definition to include whether constituents' views are discussed. We find that accounting firms appear to have significantly less influence than other stakeholders. We also find that the IASB reacts less favourably to UK proposals but comments from the US are more likely to be discussed. A lack of fairness (real or perceived) could jeopardise perceptions of the procedural legitimacy of the due process and ultimately impair the IASB's cognitive legitimacy. 


\section{Introduction}

"The genius of the FASB's due process is the cultivation of the belief among constituents that their input exerts some degree of influence upon the ultimate content of standards." Fogarty (1994: 220)

Fogarty's (1994) review of the FASB standard-setting process identified a series of constraints, opportunities and dilemmas. The question of whether certain stakeholder groups hold greater levels of (relative) influence has been the subject of much work and researchers have studied this phenomenon in both domestic and international contexts (e.g. Martens and McEnroe, 1991, 1998; Kwok and Sharp, 2005; Cortese, Irvine and Kaidonis, 2010). Almost invariably, influence and legitimacy are considered together (Hussein and Ketz, 1991; McEnroe, 1993; Tutticci, Dunstan and Holmes, 1994; Suchman, 1995; Larson, 2002; Chua and Taylor, 2008; Burlaud and Colasse, 2011; Danjou and Walton, 2012). This paper reviews the IASB's standard-setting due process in relation to the complex and controversial subject of financial instruments disclosures (International Financial Reporting Standard 7 Financial Instruments: Disclosures [IFRS 7], 2005) through the lens of legitimacy theory. In particular, this study investigates the following research questions $(\mathrm{RQ})$ :

RQ1: Is there evidence that certain stakeholder groups are more influential (measured in terms of (i) discussed and (ii) accepted proposed changes) than their peers in the financial instruments disclosure standard-setting process?

RQ2: Is there evidence that constituents in certain jurisdictions are more influential than others in the financial instruments disclosure standard-setting process?

This study is motivated, at least in part, by criticisms of, and challenges to, the IASB's procedural legitimacy (e.g. Larson and Herz, 2013; Burlaud and Colasse, 2011; Kwok and Sharp, 2005). This is an important issue within an accounting standard-setting context. Procedural legitimacy is a type of moral legitimacy which can be created (lost), maintained, and built (impaired) according to levels of perceived independence and impartiality (Suchman, 1995). Suchman (1995) distinguishes legitimacy into three primary forms: pragmatic, moral and cognitive. 
These are known to co-exist, overlap and intertwine (Brinkerhoff, 2005; O'Dwyer, Owen and Unerman, 2011) and prior work suggests that there is a "durability pendulum" (O'Dwyer, Owen and Unerman, 2011: 36). Pragmatic legitimacy is considered to be the easiest form to obtain but the least durable, whereas cognitive legitimacy is the most difficult to obtain but the most durable once it is there (O'Dwyer, Owen and Unerman, 2011, Cashore, 2002; Kumar and Das, 2007). Cognitive legitimacy is the result of constituents' long-term experiences and their perceptions of the organisation's on-going pragmatic and moral legitimacy (Kumar and Das, 2007). Thus, concerns over the moral (procedural) legitimacy are not only immediately problematic, but they also put at risk levels of pragmatic and cognitive legitimacy (O'Dwyer, Owen and Unerman, 2011).

On the one hand, some believe that the answer to the IASB's procedural legitimacy problem lies with the provision of greater transparency and hence there have been calls over the years for improvements (Tutticci, Dunstan and Holmes, 1994; Yen, Hirst and Hopkins, 2007; Stenka and Taylor, 2010). On the other hand, increasing transparency is likely to be self-defeating as it exposes the processes to public scrutiny (Herbohn and Herbohn, 1999: 421) and does not necessarily lead to better decision-making. Johnson and Solomons (1984) argued that open public debate was required to justify decisions made and actions taken; without this, there are fears that this process might be viewed as symbolic rather than substantive (e.g. Fogarty, 1994; Weetman, 2001). This is an important issue which can now be addressed.

The IASB has responded to these transparency concerns by making available documentation dating back to 2001 which includes Board minutes, technical working group minutes and staff observer notes ${ }^{1}$. This study considers the evolution of IFRS

\footnotetext{
${ }^{1}$ For ease of access reasons, we would recommend that researchers who are interested in reviewing the widest possible range of IASB documentation available, might consider those standard-setting projects which are either recently completed or on-going. While it is possible to access summaries of Board discussions from 2001 onwards (http://www.ifrs.org/Updates/IASB-Updates/Pages/IASB-Updates.aspx), for projects pre-2006 (note: it is possible that this date will shift forward as time elapses), much of the remaining detail including comment letters, observer notes and details of joint working group meetings have been archived (link to all projects since 2006 in alphabetical order: http://www.ifrs.org/Current-Projects/IASB-

Projects/Pages/All_projects.aspx). For projects that pre-date these, details can be requested directly from IASB staff and it is useful to contact the technical officer heading up the working group. For example, during our study we contacted the technical officer in charge of the financial instruments working group. It is also useful to note that through the search function of IFRS.org archived information can be found e.g. the first 50 comment letters related to ED 7 can be found at: http://www.ifrs.org/Documents/Disclosures10041_50.zip.
} 
7 from initiation (2002) through to approval (2005). Due to the complex and controversial nature of financial instruments reporting (Gebhardt, 2012), the accounting community and standard-setting bodies' credibility as an authority have been brought into question (Le Guyader, 2013). Hence, we should not be surprised if the Board allowed themselves to be guided by constituent opinion during the due process to maintain its perceived legitimacy (Richardson and Eberlein, 2011). The principal advantages of examining IFRS 7 are: first, documentation relating to meetings of the Board and technical working group was available covering the whole period; second, this is an area where there were strongly competing interests and conflicting opinions between stakeholders and across jurisdictions; and third, there have been ex-post criticisms of IFRS 7's requirements (Walton, 2004; Burlaud and Colasse, 2011; Harrington, 2012; Gebhardt, 2012).

Until now, prior work has relied almost exclusively on vote-counting systems to measure the relative influence of stakeholder groups - largely overlooking the potential implications of jurisdictional bias (see Zeff, 2002, 2007) and ranking comments equally (see McEnroe, 1993) - and defined constituent success as the number of comments accepted as a proportion of those made (e.g. Yen, Hirst and Hopkins, 2007; Kwok and Sharp, 2005). One problem with this narrow definition of success is that success is not one-dimensional. This study aims to refine and improve this definition as well as proposing a workable methodological approach which future researchers might employ.

Early work clung tightly to the underlying presumption that respondents actively supported (opposed) regulations that promoted (frustrated) self-interest during the due process (Cooper and Sherer, 1984). Whilst this may be one explanation, the

Constituents also make information available through their websites. However, to ensure completeness in the data gathering exercise, it is important to know what you are searching for. To this end, Deloitte's IAS Plus resource is helpful in filling the gap. This site provides a full suite of documents released by the IASB as well as other stakeholder organisations. This is updated on a monthly basis and, by way of illustration, the link to ED 7's release can be found at: http://www.iasplus.com/en/news/2004/July/news1406. Furthermore, the Big 4 accounting firms write up their own observer notes for IASB meetings and make them available on their websites. For example, the following is a link to Deloitte's observer notes from the 'Disclosure Initiative' meeting held during October 2014: http://www.iasplus.com/en/meeting-notes/iasb/2014/october/disclosureinitiative-2. Many of the large accounting firms also provide guidance notes and commentary to their (current and potential) clients which are available online, for instance, a link to PwC's financial reporting guidance can be found at: http://www.pwc.com/gx/en/ifrs-reporting. 
position has been modified and extended over the years and most commentators now agree that the active engagement of stakeholders stems from a political and social agenda as much as a technical one, i.e. not necessarily dominated by the economic (direct cost) notion of self-interest (Demski, 1973; Sutton, 1984; Puro, 1984; Mitchell and Sikka, 1993; McLeay, Ordelheide, and Young, 2000; Zeff, 2002, 2007; Whittington, 2005).

Furthermore, it is widely held that socio-political bodies, such as the IASB, must be seen to be acting fairly and without bias to create, maintain and build their legitimacy (e.g. Hussein and Ketz, 1991; McEnroe, 1993; Tutticci, Dunstan and Holmes, 1994; Suchman, 1995; Chua and Taylor, 2008; Danjou and Walton, 2012). Indeed, theorists go further than this in proposing that a legitimate decision-making organisation must exist to facilitate the continuance of the institutional environment as a whole (e.g. Mintzberg, Raisinghani and Theoret, 1976; Scott, 1981; Fogarty, 1993; Chua and Taylor, 2008). The standard-setting literature unites on the principle that any unfair bias shown towards one group risks impairing stakeholders' perceptions of the standard-setters' cognitive legitimacy, otherwise known as 'takenfor-grantedness' (Suchman, 1995: 582).

Achieving perceived fairness, however, is clearly not straightforward. Accounting regulations ignite competing positions and conflicting interests amongst constituents. In this milieu, some stakeholders will simply be better informed than others through a combination of knowledge and experience. Therefore, it seems unavoidable that there will be times when the standard-setter will (and should) deliberately allow certain responses (respondents) to carry higher levels of relative influence (e.g. Larson, 2002). Thus it is overly restrictive to define relative influence and success according to the number of constituent proposals that are accepted.

To overcome this issue we first classified comment letter responses into one of three categories: outcome-oriented; theory-oriented; or, other (Yen, Hirst and Hopkins, 2007). The outcome-oriented comments (i.e. those that requested amendments) were then analysed according to their nature and weight (minor, moderate or major). This study introduces a usable weighting system to prevent all comments being mistakenly treated equally. A comment requesting a change to a misspelt word 
should not be viewed as the equivalent of a request to delete a paragraph. Respondents were sub-divided firstly between stakeholder groups and secondly according to jurisdiction. Following this, we reconciled the Exposure Draft (ED) with the Standard on a word-by-word basis to establish what changes had been made and then reconciled whether the changes proposed by letter writers had been adjusted for or not. Finally, we reviewed IASB discussion documentation to see whether the issues - accepted or otherwise - had been discussed and whether this impacted on acceptance.

In summary, this study contributes to the literature in three ways. First, this study tests for jurisdictional influence. The emergence of an 'international' financial reporting community alongside the IASB-FASB convergence project means that this is an important issue which should be considered alongside the influence of stakeholder groups. Second, as with several papers before it, this study examines lobbying influence (persuasiveness). However, rather than viewing success as the number of votes versus accepted proposals, we also investigate whether constituents' proposals are discussed by the standard-setter. While 'accepted proposals' is clearly one indicator of constituent influence, if the comments are not discussed it is unlikely an amendment would be made. Discussion is the first phase of a multi-stage persuasiveness process. Furthermore, constituents' request amendments to requirements for a variety of reasons including economic, social and political. Therefore, another measure of success is having your voice heard. Third, we undertake a multi-phase manual content analysis that enables us to analyse each comment individually and explore whether any influence is consistent between requests for minor, moderate and major changes. We introduce this weighting system to mitigate treating all comments equally regardless of the nature of the proposed outcome.

This paper continues as follows: Section 2 discusses background, prior literature and theory; Section 3 introduces the research methods; Section 4 presents and discusses the findings; and finally, Section 5 summarises and concludes.

\section{Background, prior literature and theory}




\subsection{Background}

The subject of financial instruments disclosure standard-setting and the role of stakeholders is interesting for several reasons. Work shows that disclosures are both value relevant (Seow and Tam, 2002; Wang, Alam and Makar, 2005) and informative (Campbell, Chen, Dhaliwal, Lu, and Steele, 2011; Kravet and Muslu, 2013). Derivative financial instruments holding and trading is significant to the global economy. The Bank for International Settlements (2012) report that the worldwide outstanding notional value of OTC derivatives was US\$632 trillion, with gross market value US\$25 trillion. In Quarter 4 of 2012 alone, the total value of the derivatives traded on organised exchanges was US $\$ 262$ trillion. The Office for National Statistics report in their 2012 Pink Book (p.180) that at the end of 2010, UK derivative assets totalled c.£3 trillion (30\% of total UK assets); and derivative liabilities also totalled c.£3 trillion ( $28 \%$ of total UK liabilities). Financial instruments, however, describes more than derivatives and for the years ended 2007/08 ${ }^{2}$, financial instruments represented over half (53\%) of the UK's 350 largest firms' assets.

The proposed requirements in the financial instruments disclosure Exposure Draft (ED 7, 2004) necessitated varying levels of quantitative and qualitative disclosures according to the scale, scope, manner and complexity in which financial instruments are used by organizations and the ways that the associated risks are managed. Accounting firms stepped forward to offer advice and seminars on this difficult and controversial topic (e.g. Deloitte, 2006; Ernst \& Young, 2007; KPMG, 2007; PricewaterhouseCoopers, 2007). Given the levels of attention and economic significance, it seems logical to expect that: (i) company management would devote considerable resource to their financial instruments disclosure strategies, and (ii) the standard setting community would closely consider the development of the requirements. Yet unfortunately, there is currently little known about these issues (see Gebhardt's [2012] discussion of non-financial firms).

\footnotetext{
${ }^{2}$ IFRS 7 came into force for years ended on or after 1 January 2007 hence the 2007/08 figures are shown above. A review of 2013/14 data shows that this percentage continues to reflect levels of financial instruments usage.
} 
Furthermore, the breadth and depth of IFRS 7 (2005; which emerged from ED 7) is unrivalled. The published Standard had 34 balance sheet disclosure requirements, a further 10 related to the income statement and equity, 49 related to risk, 2 related to adoptions and exemptions and 38 other requirements. These 133 requirements can be further broken down as: 57 hard rules, 47 soft rules $^{3}$, and 29 principles. The principles-based requirements cover sensitive issues such as market, credit and liquidity risk. Despite the lengthy discussion period, the requirements have been criticised ex-post (Burlaud and Colasse, 2011).

\subsection{Stakeholder groups}

There is some evidence that certain stakeholders exhibit greater levels of influence over the standard-setting process (e.g. Kwok and Sharp, 2005) but the results are not generalisable. This is unsurprising. There is a strong case that relative influence is context-specific (Weetman, 2001). Studies from the US, UK, Australia and elsewhere suggest that the standard-setting process is neither systematically aligned to any group nor dominated by one (e.g. Brown, 1981; Sutton, 1984; Tutticci, Dunstan and Holmes, 1994; McLeay, Ordelheide and Young, 2000; Zeff, 2002; Kwok and Sharp, 2005; Giner and Arce, 2012). Throughout the prior work, influence has been associated with persuasion and evidence suggests that levels of persuasiveness shift between groups according to the issue under review (Martens and McEnroe, 1991, 1998; Cortese, Irvine and Kaidonis, 2010). Indeed, the optimum position for the standard setter might be to keep all parties "optimally disgruntled" (Fogarty, 1994; Daley and Tranter, 1990).

Much attention has been devoted to establishing whether the elite (Big Four) accounting firms have special influence (Puro, 1984, Hussein and Ketz, 1991). Many have argued that these firms actively favour complexity to promote 'mystique' and support regulation changes that are likely to increase their fee income by virtue of additional audit effort, lifting entry barriers and raising reputational capital (e.g. Puro, 1984; Willmott, 1986; McLeay, Ordelheide, and Young, 2000; Cortese, Irvine and Kaidonis, 2010). Their strength is thought to derive from being alumni in the

\footnotetext{
${ }^{3} \mathrm{Hard}$ rules provide guidance as to what is permissible in advance whereas soft rules require judgement to be employed.
} 
decision-making process as well as their knowledge, expertise, experience, resources and IASC (IFRS) Foundation funding levels (US Senate Metcalf Committee Report, 1976; Puro, 1984; Cooper and Sherer, 1984; Hussein and Ketz, 1991; Mitchell and Sikka, 1993; Georgiou, 2010; Financial Reporting Council, 2012). The evidence to support this influence hypothesis, however, is mixed and inconclusive. It might be that accounting firms' publicly made comments may not be representative of those made privately, or that observable levels of influence differ to levels during the non-observable phases of the process. Again, however, there is little to suggest that this is the case (Georgiou, 2004, 2010).

While the elite audit firms have attracted the most attention during the standardsetting process, the stakeholder group who has been found to be disproportionately favoured 4 are preparers (Kwok and Sharp, 2005). It would seem however that their persuasiveness is significantly reduced when they are unsupported by other constituents or networks (McLeay, Ordelheide and Young, 2000). In the past, they have been the most active respondents during the observable phase (Kwok and Sharp, 2005; McLeay, Ordelheide and Young, 2000; Larson, 1997) but this is generally no longer the case. A review of recent exposure drafts' comment letters indicates that there has been a shift towards Regulatory and Professional Bodies ${ }^{5}$ (RPBs) engaging on their behalf (Larson and Herz, 2013 [for a summary, see appendix B, pp.146-148]).

This shift should come as no surprise. On a practical note, the funding pattern has changed $^{6}$. There has been a recent move towards the IASB receiving donations

\footnotetext{
${ }^{4}$ In terms of proposed changes being accepted.

${ }^{5}$ Please note that RPBs includes the representative industry bodies.

${ }^{6}$ The funding arrangements have changed substantively in terms of their scope and their nature. In 2006 a funding review was undertaken and four underpinning principles were agreed: broad based, compelling, openended and country- or jurisdiction specific. These were revised and refined as part of the IFRS Foundation Strategy Review 2011 (2012) which briefly outlines the changes and the rationale (p.22): "At the outset, the Foundation was financed through voluntary contributions by some 200 organisations. Occasionally, this partial dependence on voluntary contributions raised two concerns by a few observers. One was a possible lack of objectivity because of the temptation to provide special consideration in the standard-setting process to important financial supporters. Conversely, there were suggestions that supporters, dissatisfied with the outcome of a rigorous standard-setting process, might withdraw funding and disrupt the IASB's work. While neither of these concerns materialised in practice, there was a sense that dependence on voluntary contributions from largely private sources was inappropriate for an organisation acting in the public interest and could deprive the organisation of necessary resources in the future. Since 2006 the Trustees have sought to establish national financing regimes, proportionate to a country's relative GDP, which would establish a levy
} 
through the RPBs as representatives of their members and/or jurisdictions rather than directly through individual entities. Secondly, RPBs and preparers share common ground. They both contend that greater disclosure has drawbacks, including increased preparation, audit and reporting costs alongside unintended consequences such as the release of competition-sensitive information. Thirdly, they are likely to be aware that coalition lobbying is generally more persuasive (e.g. Cortese, Irvine, and Kaidonis, 2010).

\subsection{Jurisdiction}

The Financial Crisis Advocacy Group ${ }^{7}$ (2009: 14) stated that the standard-setting due process was set up "to ensure that all voices in all geographical regions have an adequate opportunity to make their view known". Their report continued: "Wide consultation also promotes excellence, neutrality, the identification of unintended consequences, and ultimately, broad acceptance of the legitimacy of the standards that are adopted". However, there are many cultural, social, economic and financial barriers impairing the ability and willingness of stakeholders from certain jurisdictions from behaving in this manner (Whittington, 2008; MacArthur, 1996, 1999; Larson and Street, 2004). Thus response rates are lower to the IASB than to domestic standard setting bodies (Larson and Herz, 2013).

Yet the issue of jurisdictional influence is often overlooked in the literature (Jorissen, Lybaert, Orens and Van Der Tas, 2014; Larson and Herz, 2013). Geographical bias has the potential to be even more divisive than showing favour towards stakeholder groups. A lack of fairness and integrity might encourage nations to withdraw from the IFRS-zone, postpone IFRS adoption, problematise enforcement, and/or reduce donations (Hail, Leuz and Wysocki, 2010; Zeff, 2002). This would fundamentally impact on the cognitive legitimacy of the IASB.

It is commonly presumed that there is an Anglo-American bias. There are several reasons for this: the importance attached to the convergence agenda (Tarca, 2004;

on companies or provide an element of publicly supported financing." (for further details see http://www.ifrs.org/About-us/IFRS-Foundation/Oversight/Financing/Pages/Financing.aspx)

${ }^{7}$ Jointly undertaken by the IASB and FASB. 
Larson, 1997; Botzem and Quack, 2007; Grinyer and Russell, 1992; Zeff, 2002), the London-based IASB headquarters reducing transaction costs and increasing opportunities for conversation (Street, 2006; Camfferman and Zeff, 2007), non-US companies listing on US stock exchanges (Parker and Morris, 2001), and the importance of the US capital markets (Tarca, 2004; Parker and Morris, 2001; Camfferman and Zeff, 2007). In more recent times, Europe has also been considered to be influential (Larson and Street, 2004; Larson and Brown, 2001; Larson, 2007). The influence of the final group - the rest of the world - remains unexplored until now.

\subsection{Forms of legitimacy}

Given that this study explores perceptions of fairness during a public process, legitimacy theory is important. There is a strategic view of legitimacy (Dowling and Pfeffer, 1975) and an institutional one (Meyer and Rowan, 1977). The latter suggests that environmental dynamics shape organisational life and structure. The former lends credence to the notion that organisational actions - such as information manipulation - can garner societal support. Suchman (1995: 574) synthesises the organisational legitimacy literature and arrives at the following definition: "legitimacy is a generalized perception or assumption that the actions of an entity are desirable, proper, or appropriate within some socially constructed system of norms, values, beliefs, and definitions". Furthermore, Woodward, Edwards and Birkin (1996: 329) provide a useful addendum to this description which suggests that organisations operate "under a mandate that may be withdrawn". There is an organisational accountability between the agent (standard-setter) and principal (society) which is enhanced when the agent does the "right" things. Referring to an accounting standard-setting context, Burlaud and Colasse (2011:24) state categorically that: "The legitimacy (of the IASB) is not innate. It is not natural or pre-existing... It is constructed and managed."

It can be unhelpful, however, to speak about legitimacy in general terms. Instead, Suchman (1995) identified three primary forms of legitimacy: pragmatic, moral and cognitive. These co-existent divisions, which operate on a "durability pendulum" (O'Dwyer, Owen and Unerman, 2011), provide a useful framework for our work. An 
organisation, such as the IASB, strives to attain cognitive legitimacy but this relies on constituents' cumulative experiences regarding the organisation's pragmatic and moral legitimacy (Kumar and Das, 2007). We briefly define these primary forms, drawing particular attention to influence (pragmatic), procedural (moral) and cognitive legitimacy given the relevance to the research questions posed by this study.

Pragmatic legitimacy refers to a sense of immediacy between organisation and audience, where discourse is dominated by self-interest. As Suchman notes (p.578), it is common for audiences to become constituents who scrutinise the actions of the organisation to evaluate the consequences for them. Whilst it is difficult to believe that any constituent exerts power in its traditional sense - i.e. a stakeholder who has a conscious and consistent ability to change accounting requirements against the wishes of the Board and other stakeholders - there is a strong argument towards one variant of pragmatic legitimacy known as influence legitimacy. Advocates of influence legitimacy believe that by relinquishing some influence to stakeholders - in this case, adjusting for certain proposed amendments to accounting standards - the organisation secures an on-going commitment from them (e.g. Palazzo and Scherer, 2006).

Moral legitimacy (or normative legitimacy) rests on the consequential notion that legitimacy is attained where an organisation 'makes the right decisions' rather than necessarily just 'making the right decisions for the constituent'. Moral legitimacy is underpinned by a belief in 'rightness' or a pro-social logic (Suchman, 1995; O'Sullivan and O'Dwyer, 2009). Captured within the boundaries of moral legitimacy is procedural legitimacy. This has frequently been called into question in the context of standard-setting (e.g. Burlaud and Colasse, 2011; Kwok and Sharp, 2005; Martens and McEnroe, 1991, 1998). Procedural legitimacy is rooted in the perception of an organisation's independence and impartiality. This can be built over time according to constituent experiences (O'Dwyer, Owen and Unerman, 2011). An organisation seeking to address procedural legitimacy concerns may choose to increase levels of transparency in the process (e.g. Fogarty, 1994; Herbohn and Herbohn, 1999). 
In Suchman's (1995) typology, the final primary form of legitimacy is cognitive legitimacy. Inevitably this is difficult to identify because of the subtlety in its definition. It is, however, probably the most powerful form because it exists where an organisation, process or procedure is considered unchallengeable or where there is thought to be no alternative ${ }^{8}$. Thus, for legitimacy scholars, organisations are generally considered to be more likely to attain higher levels of cognitive legitimacy where their decisions are perceived to be pragmatically and morally centred (e.g. Parsons, 1960; Suchman, 1995; O’Dwyer, Owen and Unerman, 2011).

There are thought to be limitations at a fundamental level to the IASB's (IASC) cognitive legitimacy. Maybe because of the monopolistic nature of standard-setting bodies, as early as the 1980's the IASC's institutional (cognitive) legitimacy was under investigation; and being defended (Wallace, 1990). Burlaud and Colasse (2011) point out that the IASB/C lacked an initial political mandate and this situation continues. Wallace (1990: 11) acknowledged the absence of a legal framework or mandate, but noted that the IASC still had sufficient authority and "broad public support" (p.22) alongside an appropriately substantive and fair procedural due process which allows them to continue.

The question of a political mandate continues to be contested. The links between IOSCO and the IASC have been used as a means to highlight the degree of perceived legitimacy for the standard-setters (Danjou and Walton, 2012; Camfferman and Zeff, 2007). Further, the continuance of good relations between the IASB and market regulators enhances this argument. There is also political support for the IASB's position (Danjou and Walton, 2012). However, without a formal legal or political mandate the IASB relies on constituent support and this, in turn, is dependent upon perceived fairness in the due process (moral, procedural legitimacy). Hence, we derive our expectation that comments from stakeholder groups regardless of jurisdiction will be treated fairly and free from bias.

\footnotetext{
${ }^{8}$ Such a situation could be considered to exist in the case of international standard setting. Since many countries (have adopted and continue to) adopt IFRS/IAS this lends a 'taken-for-grantedness' to iGAAP and the IASB. It is costly to make a transition to a new regime (politically, economically and socially). Nevertheless, there are alternatives, for example, a return to domestic GAAP or a move to US GAAP.
} 


\section{Research methods}

\subsection{Background}

The research focuses on a detailed analysis of the public comment letters, minutes of IASB Board meetings and notes from technical working group meetings. Lobbying research has by and large been forced to focus on public comment letters to measure levels of influence (Jorissen, Lybaert, Orens and Van Der Tas, 2012; Yen, Hirst and Hopkins, 2007; Kwok and Sharp, 2005; Tutticci, Dunstan and Holmes, 1994). However, there is evidence that suggests this might not be such a problem. For example, Georgiou (2004: 230) suggests that: "Overall comment letters appear to be a good proxy for the use of other, less overt, lobbying methods".

The principal criticism levied against this comment-letter oriented work is that it relies on a system of naïve vote-counting which fails to take into account: (i) whether the response is representative of the stakeholder's viewpoint, and (ii) the relative strength of the response. In defence against the former, some fall back on public choice theory (Giner and Arce, 2012: 661) and argue that constituents are motivated by self-interest and that "participants... usually provide arguments to support their positions". The relative strength problem has proved a more thorny issue which few have tried to address (McEnroe [1993] being a notable exception).

As with prior work, we adopt a pluralist framework (see Giner and Arce, 2012; Kwok and Sharp, 2005; McLeay, Ordelheide and Young, 2000) whereby we measure relative influence as a function of the level of proposal acceptance measured against total proposals made. Influence operates on the basis of persuasiveness. Amongst others, Giner and Arce (2012: 661) claim to review "the entire process: the comment letters, the underlying arguments and the IASB's decisions". Our analysis includes these elements but the reconciliation between ED 7 and IFRS $7^{9}$ and the inclusion of the additional IASB documentation available (meeting notes) allows us to add an extra dimension to our understanding of the key variable: relative influence. There seems to be a problem with a persuasiveness assumption, which proposes that one constituent has more influence because their comments are accepted more

\footnotetext{
${ }^{9}$ Available on request.
} 
frequently. Therefore we extend this definition by contributing a second component, namely, whether the comment is discussed. This is the first study to undertake this analysis and thus contributes a more refined methodological approach to the existing literature.

\subsection{Comment letter and meeting notes coding}

A stand-alone financial instruments disclosure standard was first discussed at Board level in 2002. An exposure draft (ED 7) was released on 22 July 2004, and a final Standard was released during August 2005 (IFRS $7^{10}$ ). Of the 30 Board meetings during the discussion period, nine discussed constituent feedback and proposed amendments to ED 7. There were also several support meetings whose consultation informed these. The ED attracted 106 comment letters and the text of all bar three of the original 50 paragraphs was amended during the process. The average response contained approximately 22 separately identifiable comments. The 2,343 responses were classified into three categories as per prior research (e.g. Yen, Hirst and Hopkins, 2007) ${ }^{11}$ as follows: outcome-oriented (475); theory-oriented (986); 'other' (882). The number of responses is within an acceptable and expected range. ${ }^{12}$

Identifying stakeholder groups is not straightforward. We followed prior research and classified responses into one of four stakeholder groups: accounting firms; preparers; users; and RPBs (e.g. Kwok and Sharp, 2005). Instead of blindly accepting that the opinions of these constituents diverged, we tested whether their responses were significantly different. We categorise stakeholders into groups of respondents by jurisdiction and by stakeholder group. We control for the quantity of responses and test the number of pages, comments and proposals against the null

\footnotetext{
${ }^{10}$ It is this version of the Standard which is the subject of this study as this was approved and made effective for years commencing on or after 1 January 2007.

${ }^{11}$ For example: Brown and Feroz, 1992: 112 responses; McEnroe, 1993: 100 responses; Tutticci, Dunstan and Holmes, 1994: 113 responses; Weetman, Davie and Collins, 1996: 104 responses; Martens and McEnroe, 1998: 20 responses; Yen, Hirst and Hopkins, 2007: 278 responses; Larson (2007: 207) reports an examination of "18 Draft Interpretations... A total of 272 respondents from 40 countries generated 714 comment letters"; Stenka and Taylor (2010) reviewed four ED's which attracted 42, 56, 36 and 60 responses respectively. ${ }^{12}$ Appropriate comparators for response levels are other Fls EDs from the same period. The combined IAS 32 Financial Instruments: Presentation (IAS 32) (2002) and IAS 39 Financial Instruments: Recognition and Measurement (IAS 39) (2002) project led to 164 responses. A number of EDs were released during 2004 detailing proposals related to IAS 39 including (number of responses in parentheses): fair value option (116); insurance contracts (61); cash flow hedge accounting of forecast intra group (58); transition and initial recognition of financial assets and financial liabilities (37). In addition, the proposed presentational (IAS 32) amendments in relation to puttable instruments (2006) attracted 88 responses. The IFRS 9 Financial Instruments (2011) (the replacement for IAS 39) exposure drafts attracted significantly greater numbers of comments. Responses were as follows: Classification and measurement ED - 245 responses; Impairment ED - 192 responses ; Hedging ED - 162 responses; IFRS 10 Leases -302 responses.
} 
hypothesis that comment letters exhibit the same characteristics. Kruskal-Wallis oneway analyses of rank tests confirm significant differences in each category (pages: $p<0.01$; comments: $p<0.01$; outcome-oriented comments: $p<0.05$ ).

To analyse the comment letters we developed a three-phase content analysis approach. A preliminary review of the comment letters and IASB documentation revealed that the number of separately identifiable comments and responses would be numerous and varied. Lobbyists responded to a wide range of issues largely, but not exclusively, structured around 10 broad questions ${ }^{13}$ posed in the 'invitation to comment'. To mitigate coding inconsistency we analysed 10 letters using the orientation framework described above. On completion of this exercise, the researchers discussed the appropriateness of the coding scheme and its ability to capture and explore issues related to legitimacy. Though this set-up work was costly, it facilitated a more precise and consistent approach through later phases. Following this, we manually coded each of the 106 letters using QSR International NVivo.

In the third phase, we separately analysed each of the outcome-oriented comments coding each specific proposal by respondent ${ }^{14}$ (Appendix A). Following this, we weighted them according to the nature and scope of their desired outcomes. Letters have become more complex over time and often contain multiple messages. Some researchers have classified letters as broadly supportive, neutral or unsupportive (e.g. Saemann, 1999; Mian and Smith, 1990) and developed basic 'for and against' systems. These have been enhanced to take account of the complexity of constituent letters. Notably Brown and Feroz (1992) assessed the level of support with specific questions, while McEnroe (1993) used external experts to rank the importance of comments. Instead, we devised a readily employable system that differentiates between minor, moderate and major proposals (Table 1).

\subsection{Intercoder reliability testing}

\footnotetext{
${ }^{13}$ The 10 questions span four pages and run to almost 1,200 words (ED 7: 4-7) therefore they have not been reproduced in full here. However, to illustrate the freedom provided by the IASB to comment on issues, Question 10 simply states: "Do you have any other comments on the draft IFRS, Implementation Guidance and Illustrative Examples?"

${ }^{14} \mathrm{~A}$ summary is provided as appendix $\mathrm{A}$. Tables available on request.
} 
Weaknesses of content analysis principally arise because 'interpretation [of text] is in part an art' (Krippendorff, 2004; Weber, 1990 [p.62]). Krippendorff (2004) argues the key problems stem from a potential lack of stability, accuracy and reproducibility. One solution to these issues is to compare the results of an independent expert's analysis with the original coder's. In this case, six letters were independently reviewed which equates to over $10 \%$ of the word count. The Kappa coefficients for intercoder reliability ( $\mathrm{k}=0.64$ to $\mathrm{k}=0.92)$ are all significant. The majority of coding dissimilarities relate to interpretations of the coding schemata rather than disagreement. Miscodings are immaterial and relate principally to 'other' issues (i.e. not theory or outcome-oriented). For robustness, we reconcile the coding of outcome-oriented comments alone and the level of agreement is well above the commonly accepted 70\% threshold (Lombard, Snyder-Duch and Bracken, 2002).

\subsection{Methods of analysis}

Our research questions ask whether some stakeholders and jurisdictions are more influential than others. In accordance with expectations of fairness in the process derived from legitimacy theory, we test our data against the null hypotheses that there will be no significant differences between the proportion of proposals accepted (rejected) and discussed (ignored) from any (1) stakeholder group, or (2) jurisdiction.

Initially, through a series of $X^{2}$ tests, we investigated whether the observable variability in the levels of success across stakeholder groups and across jurisdictions was significant. First, we examined the relative influence of (1) stakeholder groups and (2) jurisdictions by testing the frequency of actual versus expected accepted (rejected) proposals on a total basis (see the left-hand 'Total' columns of Tables 2 and 3). We applied the usual process of $X^{2}$ tests to calculate expected rates. For example, we calculated the "expected" RPBs acceptance rate as: the total number of RPBs outcome-oriented comments (330), multiplied by the total number of accepted outcome-oriented comments across all stakeholder groups (211), divided by the total number of outcome-oriented comments (475).

Second, we examined the frequency of actual versus expected acceptance by (1) stakeholder group and by (2) jurisdiction, across the three classification categories: 
(i) minor, (ii) moderate, and (iii) major (see the second to fourth columns of Tables 2 and 3). Third, we tested the frequency of actual versus expected, discussed (ignored) comments, by (1) stakeholder group and (2) jurisdiction (see the fifth to eighth columns of Tables 2 and 3 ).

We are alert to the issues of unreliability stemming from low cell frequencies (commonly accepted to be five; Camilli and Hopkins, 1978). Combining categories, as usually suggested, would detrimentally impact on the fineness of the data as well as the relevance and importance of the cross-respondent analysis. Some argue that this minimum number is arbitrary and that it may be as low as one, provided that no more than $20 \%$ of the cells had frequencies less than five (Cochran, 1954: 420). Nevertheless this secondary analysis was run. Where this could not be satisfied, Fisher's exact test was used for $2 \times 2$ comparisons. In the findings section that follows, we present the unadjusted (Pearson) chi-square results but note that the Cochran chi-square results provide no indication of unreliability of the former.

As a second phase of testing, we undertook binomial distribution tests to investigate respondents' relative influence in greater detail (results presented in tables 2 \& 3). Responses from each stakeholder group and jurisdiction were investigated to ascertain whether: firstly, the final text of IFRS 7 was amended in light of the outcome-oriented comment, and secondly, whether the comment was discussed by the Board. Again, based on expectations derived from legitimacy theory we would expect to see no evidence of an observable bias. We test against the null hypotheses that there will be no significant differences between actual versus expected (a) acceptances and (b) discussions, of (i) minor, (ii) moderate or (iii) major proposals, by (1) stakeholder group or by (2) jurisdiction.

\section{Findings}

\subsection{Descriptive analysis}

With the exception of the single user respondent, accounting firms prepare the longest letters (8.6 pages) and make significantly more comments per letter than the other groups (44.4). RPBs produce the highest number of letters (77) and the most comments $(1,632)$. Preparers have relatively lower response levels than has been 
previously observed in similar studies (Weetman, 2001; Kwok and Sharp, 2005; McLeay, Ordelheide and Young, 2000). It is possible that the decrease in individual preparer responses is offset by the increase in the quantity of RPB responses i.e. representative organisations are responding on behalf of their members. ${ }^{15}$ Theoretically, constituents' active engagement (support) in the due process is preferable from a legitimacy perspective (Fogarty, 1993; Suchman, 1995; Chua and Taylor, 2008) and we provide evidence of this. However, in line with prior work, we also highlight a passive user (investor) community (e.g. Durocher, Fortin and Cote, 2007); at least during this public phase of the due process.

We summarise our findings in Tables 2 and 3. Table 2 analyses amendments by acceptance and rejection across stakeholder groups. Table 3 analyses amendments by acceptance and rejection across jurisdictions. Table 2 shows a breakdown of the 475 proposed changes analysed by stakeholder group (user [11], preparers [55], accounting firms [79] and RPBs [330]) while Table 3 provides a breakdown by jurisdiction (Europe excluding the UK [201], Rest of the World [62], UK [120] and US [92]). These are further analysed according to whether: (i) they were accepted (211) or not (264), (ii) whether they were minor (24), moderate (227) or major (224) proposed amendments, and finally, (iii) whether the comment was discussed at an IASB Board or working group meeting (314) or not (161). These recorded levels of involvement are broadly consistent with those of similar studies (e.g. Stenka and Taylor, 2010; Yen et al., 2007; Kwok and Sharp, 2005; Tutticci, Dunstan and Holmes, 1994) and thus indicate a long-term active support which is considered essential to establish levels of "taken for grantedness" (e.g. O'Dwyer, Owen and Unerman, 2011).

\section{Insert tables 2 and 3 here}

As we have noted in the literature review, to maintain procedural (moral) legitimacy it is desirable to have a fair and transparent due process that is free from observable bias (Suchman, 1995; Kwok and Sharp, 2005; Chua and Taylor, 2008) unless there is sufficient reason to act otherwise (Larson, 2002). The $x^{2}$ tests, as described in

${ }^{15}$ See footnote 6 for details of changes to funding arrangements which aim to shift emphasis from individual entities to representative organisations. 
section 3.4, show no significant difference between actual and expected distributions in each table, with one exception. Based on the first column of Table 2, testing total accepted comments and total rejected comments against expectations, the $X^{2}$ test indicates that the null hypothesis may be rejected at a significance level of $5 \%$ $(p=0.0500)$. Based on the first column of Table 3, responses from different jurisdictions appear to be treated fairly and free from bias on the basis of total accepted comments and total rejected comments $(p=0.4529)$. When the successful comments are analysed according to their weighting classifications of minor, moderate and major, the $x^{2}$ tests confirm our expectations that the IASB acted fairly and the process appears to be free from bias across both groups and jurisdictions. Further, these tests indicate no observable bias towards any stakeholder group or jurisdiction when deciding which proposals were discussed.

Applying binomial distribution tests, as reported in Tables 2 and 3, we note, however, that levels of influence varied considerably between stakeholder groups and jurisdictions. We discuss these differences in sections 4.2 and 4.3 , drawing on the results of the binomial tests. Where cell frequencies are less than 5 , we report these as "no result" (+) in the tables.

\subsection{Stakeholder group analysis}

The binomial distribution tests of the results of the stakeholder group indicate that the IASB apparently favoured the RPBs' minor proposals (10) $(p=0.039)$, and that preparers' comments (43) were discussed more than would be expected $(p=0.014)$. We note, however, in line with McLeay, Ordelheide, and Young's (2000) study that this pro-discussion bias is not translated into higher acceptance levels, because there are no significant results for acceptance of preparer's comments.

Our findings also reveal that the IASB does not appear to treat accounting firms' outcome-oriented comments evenly. Despite expectations derived from the assumption that the elite accounting firms will carry greater influence in the due process (US Senate, Metcalf Committee Report, 1976; Puro, 1984; Hussein and Ketz, 1991; Mitchell and Sikka, 1993; Sikka, 1992; Mitchell and Sikka, 1993; Brown, 2006; Financial Reporting Council, 2012), instead these firms appear to have 
significantly more rejected $(55)(p=0.004)$ proposals than their peers. Their major (26) $(\mathrm{p}=0.001)$ and moderate (25) $(\mathrm{p}=0.075)$ comments are statistically significantly rejected at the $1 \%$ and $10 \%$ levels respectively. Though the Board and working groups considered the comments of the accounting firms fairly for discussion purposes ( $X^{2}$ tests indicate that no bias in the IASB's comment discussion patterns across stakeholder groups), it seems that post-discussion the comments stood a statistically significantly greater chance of being rejected (29) $(p=0.027)$.

Prior work suggests that stakeholders and constituents may be surprised by this result (Georgiou, 2010). Instead, however, we believe that this is not an entirely unexpected outcome. One stream of literature focuses on the potential weakness in the system that arises as a result of the strength of certain groups, including accounting firms, in the due process and hence undue levels of influence (e.g. Hussein and Ketz, 1991; Puro, 1984). However, this could be considered somewhat myopic for it is also important to consider the longer-term legitimacy of the agent (the accounting firms) and the organisation (the standard-setter) (cf. Burlaud and Colasse, 2011). In particular, it is worth acknowledging the potential negative impact that any widely observable procedural bias resulting from excessive influence would have on the durability pendulum of legitimacy dimensions. A decrease in perceived moral (procedural) legitimacy is likely to also impact on pragmatic legitimacy and cognitive legitimacy (Brinkerhoff, 2005; O'Dwyer, Owen and Unerman, 2011).

The majority of accounting firms' proposed amendments were rejected (70\%) and there is nothing wrong with this. The preservation of the moral and cognitive legitimacy of the organisation rests on the Board being able to reject proposals which they do not think are appropriate (Larson, 2002). By virtue of the increased transparency in the due process - through the introduction of meeting notes and other associated documentation - this study has reviewed whether proposals are being considered and discussed. Given that accounting firms' proposals are being discussed in an even manner before being rejected increases the validity and reasonableness of the rejection decision.

\subsection{Jurisdiction analysis}


When we examine jurisdictional categories (i.e. UK, Europe, US and ROTW) and the classifications of comments (i.e. minor, moderate, major), the binomial distribution testing results show that the IASB does not appear to act with neutrality towards responses from certain jurisdictions. The binomial distribution tests show that moderate UK proposals (35) are significantly more rejected than those from other regions $(p=0.013)$. However, minor proposals arising from the US (8) appear to have greater relative influence $(\mathrm{p}=0.025)$ and US outcome-oriented comments are more likely to be discussed (68) ( $p=0.033)$, and are subsequently more likely to be accepted $(44)(p=0.069)$ than those from any other geographical respondent group.

We propose that responses from the US may have been deemed more insightful because of US firms' greater usage and reliance on financial instruments-based risk management programmes than other jurisdictions. Additionally, US regulators and standard-setters were first movers in the design and implementation of similar requirements and therefore US-based constituents could speak from experience (SFAS 119 [Oct, 1994]; SEC FRR No. 48 [Jan, 1997]; SFAS 133 [June, 1998]). While this could be claimed to be further evidence of an Anglo-American bias (Zeff, 2002; Botzem and Quack, 2007), given that there is no evidence of a UK bias, a further possible explanation is that US success can be linked instead to a greater level of experience and knowledge. While this result may appear to run contrary to expectations of neutrality derived from legitimacy theory, in reality the IASB should accept outcome-oriented comments which improve the reporting regulations (Larson, 2002). Indeed, cognitive legitimacy is built-up over time and, when attained, is highly durable. Thus, while constituents continue to actively support the due process, which they appear to, it is possible to suggest that the IASB's cognitive legitimacy endures.

\section{Discussion and conclusion}

Prior work has sought to measure relative levels of constituent success on the basis of vote-counting systems often by determining whether proposed changes during the discussion period made through public comment letters were accepted (e.g. Willmott, 1986; Kwok and Sharp, 2005; Chua and Taylor, 2008; Burnett, Chen and Gunny, 2013). Instead, our study identifies whether these constituent comments are (i) discussed by the standard-setter and their representatives and (ii) whether they are accepted. We also explore these two variants of success across stakeholder 
groups and jurisdictions. We reviewed comment letter responses to ED 7 alongside IASB discussion documentation (Board and working group meeting minutes) and reconciled these with IFRS 7 to determine whether there was any observable bias in the due process. In line with prior work, we find that whilst no party dominates, there is some evidence of bias (e.g. Giner and Arce, 2012; Kwok and Sharp, 2005; Hussein and Ketz, 1991).

There is an expectation of neutrality from legitimacy theory. A standard-setter that shows favour to one group over any other puts at risk constituents' perceptions of their procedure i.e. moral legitimacy in the form of procedural legitimacy. There is a wealth of prior work which indicates that standard-setters' decisions and processes must be seen to be fair and free from bias (Hussein and Ketz, 1991; McEnroe, 1993; Fogarty, 1993; Tutticci, Dunstan and Holmes, 1994; Suchman, 1995; Chua and Taylor, 2008; Danjou and Walton, 2012). As the three forms of legitimacy pragmatic, moral and cognitive - operate on a durability pendulum, an impairment to one form may have an impact a similar effect on the others (O'Dwyer, Owen and Unerman, 2011; Kumar and Das, 2007).

Despite concerns that the IASB favours the elite accounting firms in the due process (US Senate, Metcalf Committee Report, 1976; Puro, 1984; Cooper and Sherer, 1984; Hussein and Ketz, 1991; Mitchell and Sikka, 1993; Financial Reporting Council, 2012), instead we find that these firms are statistically significantly less influential. Whilst accounting firms' comments are discussed fairly by the Board, this group's moderate and major proposals are rejected in greater numbers than one would expect given the average proposal acceptance rates for constituents on the whole.

In terms of jurisdictional influence, we find a negative bias towards UK comments and a positive bias towards US. These results could be interpreted as evidence to support the Anglo-American bias (Larson, 1997; Zeff, 2002; Botzem and Quack, 2007). However, it would be foolhardy to rule out other explanations. Not least, that US standard-setters introduced similar reporting requirements before the IASB and therefore US constituents' likely had superior knowledge and experience in this context. Therefore their comments may have been deemed to be more useful to the 
process. There is a strong argument that standard-setting influence is contextspecific (e.g. Weetman, 2001; Martens and McEnroe, 1991, 1998; Cortese, Irvine and Kaidonis, 2010) and that the standard-setter should accept (reject) comments that improve (impair) the quality of the final reporting requirements (e.g. Larson, 2002). Further, cognitive legitimacy is built over time and is highly durable therefore continuing active support - as evidenced in this study - suggests continued constituent support for the moral and pragmatic dimensions of legitimacy.

In summary, this study provides a more sophisticated method to analyse constituents' participation in the due process than basic vote-counting. We analyse whether certain stakeholders have greater relative levels of influence in terms of 'acceptance' rates (which prior studies denote as 'success') and whether the comment is discussed. By drawing on a legitimacy theory framework, we propose that observably higher levels of influence can place at risk constituents' perceptions of the standard-setting due process' procedural legitimacy and, ultimately, the cognitive legitimacy of the organisation and the environment. However, given the often complex and mostly private decision-making element to the process, claims that higher influence is directly associated with a fall in perceptions of procedural legitimacy can be overly simplistic as context is important as are constituent knowledge and experience.

There are two inter-related limitations of our study and we recommend future researchers follow this up. The first issue is that we consider one standard in isolation. It is possible that responses to this ED may have been influenced by a longer-term political or technical agenda which we cannot ascertain. We recommend that future researchers explore whether these results are generalisable between standards. Note, however, that the method of manual coding and analysis does not lend itself neatly to enquiries of large data sets. The researcher is required to apply their technical knowledge to be able to interpret the meaning of the comment and the subsequent discussion and interpretation. This means that it can be resource intensive, time-consuming work. Linked to the above is that the small sample makes more sophisticated statistical analysis approaches less employable and the results of those methods less robust. 


\section{References}

Bank for International Settlements (2012). Triennial Central Bank Survey of foreign exchange and derivatives market activity in 2012. Available at http://www.bis.org/ (accessed 20 June 2013).

Botzem, S., Quack, S. (2009). (No) limits to Anglo-American accounting? Reconstructing the history of the International Accounting Standards Committee: a review article. Accounting, Organizations and Society, 34(8), 988-998.

Brinkerhoff, D. W. (2005). Organizational legitimacy, capacity and capacity development, Discussion Paper No. 58A, Maastricht: The European Centre for Development Policy Management.

Brown, P. R. (1981). A descriptive analysis of select input bases of the Financial Accounting Standards Board. Journal of Accounting Research, 19(1), 232-246.

Brown, A. M. (2006). The financial milieu of the IASB and AASB. Australian Accounting Review, 16(1), 85-95.

Brown, D., Feroz, E.H. (1992). Does the FASB listen to corporations. Journal of Business, Finance \& Accounting, 19(5), 715-731.

Burlaud, A., Colasse, B. (2011). International accounting standardisation: is politics back? Accounting in Europe, 8(1), 23-47.

Burnett, B., Chen, H., Gunny, K. (2013). Auditor lobbying and audit quality. Working paper, University of Miami Business School.

Camfferman, K., Zeff, S. (2007). Financial Reporting and Global Capital Markets. Oxford University Press, Oxford.

Camilli, G., Hopkins, K. D. (1978). Applicability of chi-square to $2 \times 2$ contingency tables with small expected cell frequencies. Psychological Bulletin, 85(1), 163.

Campbell, J. L., Chen, H., Dhaliwal, D. S., Lu, H. M., Steele, L. B. (2011). The information content of mandatory risk factor disclosures in corporate filings. Review of Accounting Studies, 19(1) 1-60.

Cashore, B. (2002). Legitimacy and the privatization of environmental governance: How non-state market-driven (NSMD) governance systems gain rule-making authority. Governance, 15(4), 503-529.

Chua, W.F., Taylor, S.L. (2008). The rise and rise of IFRS: An examination of IFRS diffusion. Journal of Accounting and Public Policy, 27(6), 462-473.

Cochran, W. G. (1954). Some methods for strengthening the common $\times 2$ tests. Biometrics, 10(4), 417-451. 
Cooper, D.J., Sherer, M.J. (1984). The value of corporate accounting reports: arguments for a political economy of accounting. Accounting, Organizations and Society, 9(3-4), 207-232.

Cortese, C.L. Irvine, H.J., Kaidonis, M.A. (2010). Powerful players: How constituents captured the setting of IFRS 6 , an accounting standard for the extractive industries. Accounting Forum, 34(2), 76-88.

Daley, L. A., Tranter, T. (1990). Limitations on the value of the conceptual framework in evaluating extant accounting standards. Accounting Horizons, 4(1), 15-24.

Danjou, P., Walton, P. (2012). The Legitimacy of the IASB. Accounting in Europe, 9(1), 1-15.

Deloitte (2006). Living with IFRS 7. Available at deloitte.com (Accessed on $6^{\text {th }}$ May, 2014).

Demski, J.S. (1973). The General Impossibility of Normative Accounting Standards. Accounting Review, 48(4), 718-723.

Dowling, J., Pfeffer, J. (1975). Organizational legitimacy: Social values and organizational behavior. Pacific Sociological Review, 122-136.

Durocher, S., Fortin, A., Cote, L. (2007). Users' Participation in the Accounting Standard-Setting Process: A Theory-Building Study. Accounting, Organizations and Society, 32(1-2), 29-59.

Ernst \& Young (2007). IFRS 7: Financial Instruments: Disclosures. Available at ey.com (Accessed on $6^{\text {th }}$ May, 2014).

Financial Crisis Advisory Group (2009). Report of the FCAG (July 28). Available at: http://www.fasb.org/ (accessed 22 May 2014).

Financial Reporting Council (2012). Reform of the Financial Reporting Council approved by Parliament, FRC PN 366.

Fogarty, T. J. (1993). Financial accounting standard setting as an institutionalized action field: constraints, opportunities and dilemmas. Journal of Accounting and Public Policy, 11(4), 331-355.

Fogarty, T. J. (1994). Structural-functionalism and financial accounting: Standard setting in the US. Critical Perspectives on Accounting, 5(3), 205-226.

Gebhardt, G. (2012). Financial instruments in non-financial firms: what do we know? Accounting and Business Research, 42(3), 267-289.

Georgiou, G. (2004). Corporate lobbying on accounting standards: Methods, timing and perceived effectiveness. Abacus, 40(2), 219-237. 
Georgiou, G. (2010). The IASB standard-setting process: Participation and perceptions of financial statement users. British Accounting Review, 42(2), 103-118. Giner, B., Arce, M. (2012). Lobbying on accounting standards: Evidence from IFRS 2 on share-based payments. European Accounting Review, 21(4), 655-691.

Grinyer, J.R., Russell, A. (1992). National impediments to international harmonization: evidence of lobbying in the UK. Journal of International Accounting, Auditing and Taxation, 1(1), 13-31.

Hail, L., Leuz, C., Wysocki, P., 2010. Global accounting convergence and the potential adoption of IFRS by the US (Part I): Conceptual underpinnings and economic analysis. Accounting Horizons, 24(3), 355-394.

Harrington, R. (2012). Discussion of 'Financial instruments in non-financial firms: what do we know?' by Günther Gebhardt (2012). Accounting and Business Research, 42(3), 291-293.

Herbohn, K.F., Herbohn, J.L. (1999). Accounting for forests in social, economic and political contexts. Accounting Forum, 23(4), 408-440.

Hussein, M.E., Ketz, J.E. (1991). Accounting Standards-Setting in the US: An analysis of power and social exchange. Journal of Accounting and Public Policy, 10(1), 59-81.

International Accounting Standards Board (released for discussion July 2004), Exposure Draft 7 Financial Instruments: Disclosures.

International Accounting Standards Board (approved 2005; effective 2007), International Financial Reporting Standard 7 Financial Instruments: Disclosures.

International Financial Reporting Standards Foundation (2012). Report of the Trustees' Strategy Review 2011. http://www.ifrs.org/ (Accessed 23 May 2014)

International Financial Reporting Standards Foundation (2013). Financing: Funding Commitments. http://www.ifrs.org/ (Accessed 10 December 2013)

Johnson, S. B., Solomons, D. (1984). Institutional legitimacy and the FASB. Journal of Accounting and Public Policy, 3(3), 165-183.

Jorissen, A., Lybaert, N., Orens, R., Van Der Tas, L. (2014). Constituents' Participation in the IASC/IASB's due Process of International Accounting Standard Setting: A Longitudinal Analysis. In Accounting and Regulation (79-110). Springer, New York. 
Jorissen, A., Lybaert, N., Orens, R., Van Der Tas, L. (2012). Formal participation in the IASB's due process of standard setting: a multi-issue/multi-period analysis. European Accounting Review, 21(4), 693-729.

KPMG (2007). IFRS 7 for investment funds: International Financial Reporting Standards. Available at kpmg.com (Accessed on $6^{\text {th }}$ May, 2014).

Kravet, T., Muslu, V. (2013). Textual risk disclosures and investors' risk perceptions. Review of Accounting Studies, 18(4), 1088-1122.

Krippendorff, K. (2004). Content analysis: An introduction to its methodology, $2^{\text {nd }}$ edition. Beverley Hills; Sage Publications.

Kumar, R., \& Das, T. K. (2007). Interpartner Legitimacy in the Alliance Development Process. Journal of Management Studies, 44(8), 1425-1453.

Kwok, W., Sharp, D. (2005). Power and International Accounting Standard Setting: Evidence from Segment Reporting and Intangible Assets Projects. Accounting, Auditing \& Accountability Journal, 18(1), 74-99.

Larson, R.K. (1997). Corporate lobbying of the international accounting standards committee. Journal of International Financial Management \& Accounting, 8(3), 175203.

Larson, R. K. (2002). The IASC's search for legitimacy: An analysis of the IASC's standing interpretations committee. Advances in International Accounting, 15, 79Larson, R.K. (2007). Constituent Participation and the IASB's International Financial Reporting Interpretations Committee. Accounting in Europe, 4(2), 207-254.

Larson, R. K., Brown, K. L. (2001). Lobbying of the International Accounting Standards Committee: the case of construction contracts. Advances in International Accounting, 14, 47-74.

Larson, R. K., Herz, P. J. (2013). A multi-issue/multi-period analysis of the geographic diversity of IASB comment letter participation. Accounting in Europe, 10(1), 99-151.

Larson, R. K., Street, D. L. (2004). Convergence with IFRS in an expanding Europe: progress and obstacles identified by large accounting firms' survey. Journal of International Accounting, Auditing \& Taxation, 13(2), 89-119.

Le Guyader, L. P. (2013). Can Accountants Understand Derivatives? Journal of Corporate Accounting \& Finance, 24(6), 49-54. 
Lombard, M., Snyder-Duch, J., Bracken, C. C. (2002). Content analysis in mass communication: Assessment and reporting of intercoder reliability. Human Communication Research, 28(4), 587-604.

McEnroe, J.E. (1993). An analysis of comment integration involving SAS 54. Abacus, 29(2), 160-175.

McLeay, S., Ordelheide, D., Young, S. (2000). Constituent lobbying and its impact on the development of financial reporting regulations: evidence from Germany. Accounting, Organizations and Society, 25(1), 79-98.

MacArthur, J. B. (1996). An investigation into the influence of cultural factors in the international lobbying of the International Accounting Standards Committee: The case of E32, Comparability of Financial Statements. The International Journal of Accounting, 31(2), 213-237.

MacArthur, J. B. (1999). The impact of cultural factors on the lobbying of the International Accounting Standards Committee on E32, comparability of financial statements: an extension of MacArthur to accounting member bodies. Journal of International Accounting, Auditing and Taxation, 8(2), 315-335.

Martens, S., McEnroe, J. (1991). Interprofessional struggles over definition: lawyers, accountants and illegal acts. Critical Perspectives on Accounting, 2, 375-384.

Martens, S.C., McEnroe, J.E. (1998). Interprofessional conflict, accommodation, and the flow of capital: the ASB vs the securities industry and its lawyers. Accounting, Organizations and Society, 23(4), 361-376.

Meyer, J. W., Rowan, B. (1977). Institutionalized organizations: Formal structure as myth and ceremony. American Journal of Sociology, 340-363.

Mian, S. L., Smith Jr, C. W. (1990). Incentives associated with changes in consolidated reporting requirements. Journal of Accounting and Economics, 13(3), 249-266.

Mintzberg, H., Raisinghani, D., Theoret, A. (1976). The structure of unstructured decision processes. Administrative Science Quarterly, 21(2), 246-268.

Mitchell, A., Sikka, P. (1993). Accounting for change: The institutions of accountancy. Critical Perspectives on Accounting, 4(1), 29-52.

O'Dwyer, B., Owen, D., \& Unerman, J. (2011). Seeking legitimacy for new assurance forms: The case of assurance on sustainability reporting. Accounting, Organizations and Society, 36(1), 31-52. 
O'Sullivan, N., O'Dwyer, B. (2009). Stakeholder perspectives on a financial sector legitimation process: The case of NGOs and the Equator Principles. Accounting, Auditing \& Accountability Journal, 22(4), 553-587.

Office for National Statistics (2012). United Kingdom Balance of Payments - The Pink Book - 2012. Available at http://www.ons.gov.uk/ (accessed on 10 March, 2014).

Palazzo, G., \& Scherer, A. G. (2006). Corporate legitimacy as deliberation: A communicative framework. Journal of Business Ethics, 66(1), 71-88.

Parker, R. H., Morris, R. D. (2001). The influence of US GAAP on the harmony of accounting measurement policies of large companies in the UK and Australia. Abacus, 37(3), 297-328.

Parsons, T. (1960). Structure and process in modem societies. Glencoe, IL: Free Press.

PricewaterhouseCoopers (2007). IFRS 7: Ready or Not. Available at pwc.com (Accessed on $6^{\text {th }}$ May, 2014).

Puro, M. (1984). Audit firm lobbying before the Financial Accounting Standards Board: an empirical study. Journal of Accounting Research, 22(2), 624-666.

Richardson, A. J., \& Eberlein, B. (2011). Legitimating transnational standard-setting: The case of the international accounting standards board. Journal of Business Ethics, 98(2), 217-245.

Saemann, G. (1999). An Examination of Comment Letters Filed in the US Financial Accounting Standard-Setting Process by Institutional Interest Groups. Abacus, 35(1), 1-28.

Scott, R. (1981). Organizations: rational natural and open systems. Englewood Cliffs, $\mathrm{NJ}$ : Prentice Hall.

Seow, G., Tam, K. (2002). The Usefulness of Derivative-Related Accounting Disclosures. Review of Quantitative Finance and Accounting, 18(3), 273-291.

Sikka, P. (1992). The politics of political contributions. Certified Accountant, May, 4647.

Stenka, R., Taylor, P. (2010). Setting UK standards on the concept of control: an analysis of lobbying behaviour. Accounting and Business Research, 40(2), 109-130.

Street, D. L. (2006). The G4's role in the evolution of the international accounting standard setting process and partnership with the IASB. Journal of International Accounting, Auditing and Taxation, 15(1), 109-126. 
Suchman, M.C. (1995). Managing legitimacy: strategic and institutional approaches. Academy of Management Journal, 20(3), 571-610.

Sutton, T.G. (1984). Lobbying of accounting standard-setting bodies in the UK and the USA: Downsian analysis. Accounting, Organisations and Society, 9(1), 81-95.

Tarca, A. (2004). International Convergence of Accounting Practices: Choosing between IAS and US GAAP. Journal of International Financial Management \& Accounting, 15(1), 60-91.

Tutticci, I., Dunstan, K., Holmes, S. (1994). Respondent lobbying in the Australian accounting standard-setting process: ED49. Accounting, Auditing \& Accountability Journal, 7(2), 86-104.

US Senate, Metcalf Committee Report (1976). The Accounting Establishment. 94 ${ }^{\text {th }}$ Congress. $2^{\text {nd }}$ Session. Washington DC: Government Printing Office.

Wallace, R. S. O. (1990). Survival strategies of a global organization: the case of the International Accounting Standards Committee. Accounting Horizons, 4(June), 1-22. Walton, P. (2004). IAS 39: where different accounting models collide. Accounting in Europe, 1(1), 5-16.

Wang, L., Alam, P., Makar, S. (2005). The value-relevance of derivative disclosures by commercial banks: A comprehensive study of information content under SFAS Nos. 119 and 133. Review of Quantitative Finance and Accounting, 25(4), 413-427. Weber, R. P. (1990). Basic content analysis, $2^{\text {nd }}$ edition. Sage: Newbury Park, CA. Weetman, P. (2001). Controlling the Standard-Setting Agenda: The Role of FRS 3. Accounting, Auditing \& Accountability Journal, 14(1), 85-108.

Weetman, P., Davie, E. S., Collins, W. (1996). Lobbying on accounting issues: preparer/user imbalance in the case of the operating and financial review. Accounting, Auditing \& Accountability Journal, 9(1), 59-76.

Whittington, G. (2005). The adoption of international accounting standards in the European Union. European Accounting Review, 14(1), 127-153.

Whittington, G. (2008). Harmonisation or discord? The critical role of the IASB conceptual framework review. Journal of Accounting and Public Policy, 27(6), 495502.

Willmott, H. (1986). Organising the profession: a theoretical and historical examination of the development of the major accountancy bodies in the UK. Accounting, Organizations and Society, 11(6), 555-580. 
Woodward, D. G., Edwards, P., Birkin, F. (1996). Organizational Legitimacy and Stakeholder Information Provision1. British Journal of Management, 7(4), 329-347. Yen, A. C., Hirst, D. E., Hopkins, P. E. (2007). A content analysis of the comprehensive income exposure draft comment letters. Research in Accounting Regulation, 19, 53-79.

Zeff, S. (2002). The Prospect of 'Political' Lobbying on Proposed Standards at the International and Country Levels: A Challenge to the IASB. Accounting Horizons, 16(1), 43-55.

Zeff, S. (2007). Some obstacles to global financial reporting comparability and convergence at a high level of quality. British Accounting Review, 39(4), 290-302. 
Table 1: Categorisation system for the relative strength of responses

\begin{tabular}{|c|c|c|}
\hline Level & Explanation & $\begin{array}{l}\text { Example(s) (paragraph references } \\
\text { relate to the text from the Exposure } \\
\text { Draft) }\end{array}$ \\
\hline Minor & $\begin{array}{l}\text { - Requests that do not } \\
\text { alter the meaning of } \\
\text { the requirement. }\end{array}$ & $\begin{array}{l}\text { - Requests for spelling or grammatical } \\
\text { changes which do not materially alter } \\
\text { the meaning of the requirement. } \\
\text { e.g. para } 3 \text { amended from: } \\
\text { "However, entities shall apply this } \\
\text { [draft] IFRS to an interest in a } \\
\text { subsidiary, associate or joint venture } \\
\text { that according to IAS } 27 \text {, IAS } 28 \text { or } \\
\text { IAS } 31 \text { is accounted for in } \\
\text { accordance with IAS } 39 \text { Financial } \\
\text { Instruments: Recognition and } \\
\text { Measurement. In these cases, } \\
\text { entities shall apply the disclosure } \\
\text { requirements in IAS } 27 \text {, IAS } 28 \text { and } \\
\text { IAS } 31 \text { in addition to those in this } \\
\text { [draft] IFRS." This exert was } \\
\text { amended to read: "However, in some } \\
\text { cases, IAS } 27 \text {, IAS } 28 \text { or IAS } 31 \\
\text { permits an entity to account for an } \\
\text { interest in a subsidiary, associate or } \\
\text { joint venture using IAS } 39 \text {; entities } \\
\text { shall apply the requirements of this } \\
\text { [draft] IFRS." }\end{array}$ \\
\hline Moderate & $\begin{array}{lrr}\text { - } & \text { Requests } & \text { that } \\
\text { propose moderate } & \text { moder } \\
\text { changes to either } \\
\text { meaning } & \text { or } \\
\text { interpretation } & \end{array}$ & $\begin{array}{l}\text { - Requests for spelling or grammatical } \\
\text { changes which alter the meaning of } \\
\text { the requirement in a material way } \\
\text { - Requests for extra guidance on } \\
\text { application } \\
\text { e.g. paragraph } 27 \text { was amended } \\
\text { from: "whether its financial } \\
\text { statements include financial } \\
\text { instruments measured at fair values } \\
\text { that are determined in full or in part } \\
\text { using a valuation technique based on } \\
\text { assumptions that are not supported } \\
\text { by observable market prices or } \\
\text { rates." It now reads: "whether the fair } \\
\text { values recognised or disclosed in the } \\
\text { financial statements are determined } \\
\text { in full or in part using a valuation } \\
\text { technique based on assumptions that } \\
\text { are not supported by prices from } \\
\text { observable current market }\end{array}$ \\
\hline
\end{tabular}




\begin{tabular}{|c|c|c|}
\hline & & $\begin{array}{l}\text { transactions in the same instrument } \\
\text { (i.e. without modification or } \\
\text { repackaging) and not based on } \\
\text { available observable market data." } \\
\text { - Requests for clarification of terms } \\
\text { e.g. paragraph 17, clarification of } \\
\text { original text: "When an allowance } \\
\text { account is used to reduce the } \\
\text { carrying amount of financial assets } \\
\text { impaired by credit losses an entity } \\
\text { shall disclose a reconciliation of } \\
\text { changes in the allowance account } \\
\text { during the period for each class of } \\
\text { financial assets." } \\
\text { Amended to read: "When financial } \\
\text { assets are impaired by credit losses } \\
\text { and the entity records the impairment } \\
\text { in a separate account (e.g. an } \\
\text { allowance account used to record a } \\
\text { collective impairment of assets) } \\
\text { rather than directly reducing the } \\
\text { carrying amount of the asset, it shall } \\
\text { disclose a reconciliation of changes } \\
\text { in that account during the period for } \\
\text { each class of financial assets. }\end{array}$ \\
\hline Major & $\begin{array}{l}\text { - } \text { Proposals that } \\
\text { request fundamental } \\
\text { changes }\end{array}$ & $\begin{array}{l}\text { - Requests for spelling or grammatical } \\
\text { changes which alter the meaning of } \\
\text { the requirement materially } \\
\text { e.g. paragraph 11, respondents } \\
\text { asked for clarification to allow them to } \\
\text { interpret and apply what was meant } \\
\text { by: "the amount of change in it its fair } \\
\text { value that is not attributable to } \\
\text { changes in a benchmark interest } \\
\text { rate". Amended to read "the amount } \\
\text { of change in its fair value that is not } \\
\text { attributable to changes in market } \\
\text { conditions that give rise to market } \\
\text { risk". In addition, a supplementary } \\
\text { guidance note is appended } \\
\text { describing what is meant by market } \\
\text { conditions. }\end{array}$ \\
\hline & & $\begin{array}{l}\text { - Requests for additional requirements } \\
\text { (previously unconsidered in the } \\
\text { exposure draft) to be included. }\end{array}$ \\
\hline
\end{tabular}







Table 2 Analysis of the outcome-oriented comments made in response to ED 7 by stakeholder group

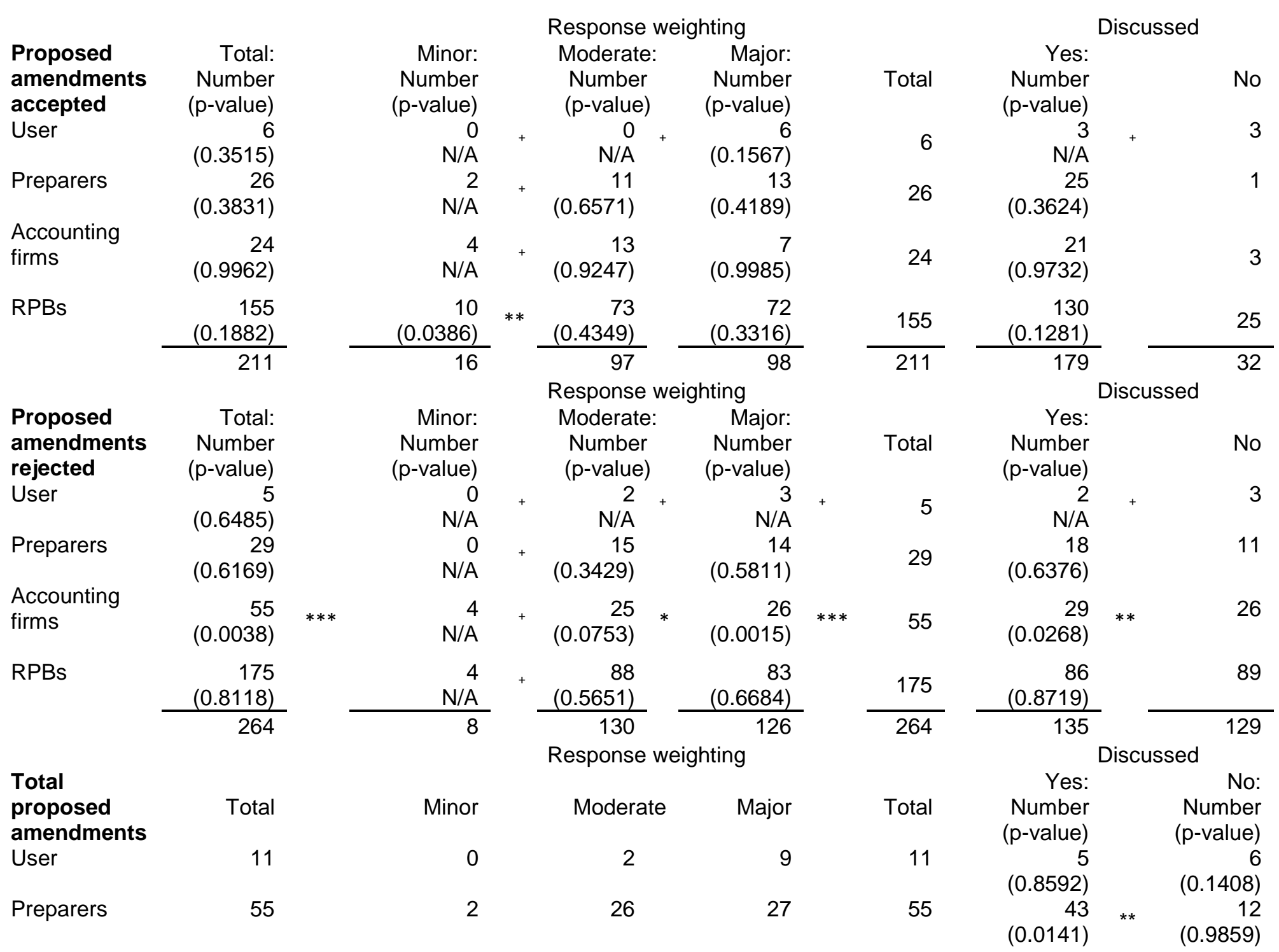




\begin{tabular}{|c|c|c|c|c|c|c|c|}
\hline $\begin{array}{l}\text { Accounting } \\
\text { firms }\end{array}$ & 79 & 8 & 38 & 33 & 79 & $\begin{array}{r}50 \\
(0.6182)\end{array}$ & $\begin{array}{r}29 \\
(0.3818)\end{array}$ \\
\hline \multirow[t]{2}{*}{ RPBs } & 330 & 14 & 161 & 155 & 330 & $\begin{array}{r}216 \\
(0.4822) \\
\end{array}$ & $\begin{array}{r}114 \\
(0.5178) \\
\end{array}$ \\
\hline & 475 & 24 & 227 & 224 & 475 & 314 & 161 \\
\hline
\end{tabular}

The table above shows the number of outcome-oriented proposals accepted, rejected and in total by stakeholder group. The table also shows results from binomial distribution tests against the null hypotheses that there will be no significant differences between actual versus expected acceptances (rejections) and discussions of minor, major or moderate proposals. The following notation scheme is applied:

$* * *=$ significant at the $1 \%$ level

** $=$ significant at the $5 \%$ level

* $=$ significant at the $10 \%$ level

$+=$ No result recorded. Cell frequency too low. 
Table 3 Analysis of the outcome-oriented of comments made in response to ED 7 by jurisdiction

Proposed amendments accepted

\begin{tabular}{|c|c|c|c|c|c|}
\hline & \multicolumn{5}{|c|}{ Response weighting } \\
\hline & Total: & Minor: & & Moderate: & Major: \\
\hline & $\begin{array}{l}\text { Number } \\
\text { (p-value) }\end{array}$ & $\begin{array}{l}\text { Number } \\
\text { (p-value) }\end{array}$ & & $\begin{array}{l}\text { Number } \\
\text { (p-value) }\end{array}$ & $\begin{array}{l}\text { Number } \\
\text { (p-value) }\end{array}$ \\
\hline \multirow[t]{2}{*}{ Europe } & 89 & 3 & & 46 & 40 \\
\hline & $(0.5410)$ & $\mathrm{N} / \mathrm{A}$ & + & $(0.5169)$ & $(0.6775)$ \\
\hline \multirow[t]{2}{*}{ ROTW } & 27 & 1 & & 15 & 11 \\
\hline & $(0.6018)$ & $\mathrm{N} / \mathrm{A}$ & + & $(0.6887)$ & $(0.4490)$ \\
\hline \multirow[t]{2}{*}{ UK } & 48 & 4 & & 15 & 29 \\
\hline & $(0.8560)$ & $\mathrm{N} / \mathrm{A}$ & + & $(0.9871)$ & $(0.4450)$ \\
\hline \multirow[t]{3}{*}{ US } & 47 & 8 & & 21 & 18 \\
\hline & $(0.1180)$ & $(0.0250)$ & ** & $(0.1184)$ & $(0.7302)$ \\
\hline & 211 & 16 & & 97 & 98 \\
\hline
\end{tabular}

$\begin{array}{rrr} & \begin{array}{r}\text { Discussed } \\ \text { Yes: }\end{array} & \\ \text { Total } & \begin{array}{r}\text { Number } \\ (p \text {-value) }\end{array} & \text { No } \\ & 75 & 14 \\ 89 & (0.5371) \\ & 18 & \\ 27 & (0.7368) & \\ 42 & & \\ 48 & (0.6476) \\ 44 & & 6 \\ 47 & (0.0693) \\ & 179\end{array}$

Proposed amendments rejected

\begin{tabular}{|c|c|c|c|c|c|c|}
\hline & \multicolumn{6}{|c|}{ Response weighting } \\
\hline & Total: & Minor: & & Moderate: & & Major: \\
\hline & $\begin{array}{l}\text { Number } \\
\text { (p-value) }\end{array}$ & $\begin{array}{l}\text { Number } \\
\text { (p-value) }\end{array}$ & & $\begin{array}{l}\text { Number } \\
\text { (p-value) }\end{array}$ & & $\begin{array}{l}\text { Number } \\
\text { (p-value) }\end{array}$ \\
\hline \multirow[t]{2}{*}{ Europe } & 112 & 1 & & 57 & & 54 \\
\hline & $(0.4590)$ & $\mathrm{N} / \mathrm{A}$ & + & $(0.4831)$ & & $(0.3225)$ \\
\hline \multirow[t]{2}{*}{ ROTW } & 35 & 2 & & 21 & & 12 \\
\hline & $(0.3982)$ & $\mathrm{N} / \mathrm{A}$ & + & $(0.3113)$ & & $(0.5510)$ \\
\hline \multirow[t]{2}{*}{ UK } & 72 & 3 & & 35 & $* *$ & 34 \\
\hline & $(0.1440)$ & $N / A$ & + & $(0.0129)$ & $\pi \pi$ & $(0.5550)$ \\
\hline \multirow[t]{3}{*}{ US } & 45 & 2 & & 17 & & 26 \\
\hline & $(0.8820)$ & $\mathrm{N} / \mathrm{A}$ & + & $(0.8816)$ & & $(0.2698)$ \\
\hline & 264 & 8 & & 130 & & 126 \\
\hline
\end{tabular}

\begin{tabular}{|c|c|c|}
\hline & $\begin{array}{c}\text { Discussed } \\
\text { Yes: }\end{array}$ & \\
\hline Total & $\begin{array}{l}\text { Number } \\
\text { (p-value) }\end{array}$ & No \\
\hline 112 & $\begin{array}{r}57 \\
(0.4629)\end{array}$ & 55 \\
\hline 35 & $\begin{array}{r}18 \\
(0.2632)\end{array}$ & 17 \\
\hline 72 & $\begin{array}{r}36 \\
(0.3524)\end{array}$ & 36 \\
\hline 45 & $\begin{array}{r}24 \\
(0.9307) \\
\end{array}$ & 21 \\
\hline 264 & 135 & 129 \\
\hline
\end{tabular}

Total proposed amendments

Response weighting

Total Minor Moderate

Major $\quad$ Total $\quad \begin{array}{rrr}\text { Number } & \begin{array}{r}\text { No: } \\ (p-v a l u e)\end{array} \\ & \begin{aligned} \text { Number } \\ (p \text {-value })\end{aligned}\end{array}$




\begin{tabular}{|c|c|c|c|c|c|c|c|}
\hline Europe & 201 & 4 & 103 & 94 & 201 & $\begin{array}{r}132 \\
(0.6250)\end{array}$ & $\begin{array}{r}69 \\
(0.3750)\end{array}$ \\
\hline ROTW & 62 & 3 & 36 & 23 & 62 & $\begin{array}{r}36 \\
(0.8625)\end{array}$ & $\begin{array}{r}26 \\
(0.1375)\end{array}$ \\
\hline UK & 120 & 7 & 50 & 63 & 120 & $\begin{array}{r}78 \\
(0.5092)\end{array}$ & $\begin{array}{r}42 \\
(0.4908)\end{array}$ \\
\hline US & 92 & 10 & 38 & 44 & 92 & $\begin{array}{r}68 \\
(0.0326) \\
\end{array}$ & $\begin{array}{r}24 \\
(0.9674) \\
\end{array}$ \\
\hline & 475 & 24 & 227 & 224 & 475 & 314 & 161 \\
\hline
\end{tabular}

The table above shows the number of outcome-oriented proposals accepted, rejected and in total by jurisdiction. The table also shows results from binomial distribution tests against the null hypotheses that there will be no significant differences between actual versus expected acceptances (rejections) and discussions of minor, major or moderate proposals. The following notation scheme is applied:

*** $=$ significant at the $1 \%$ level

** $=$ significant at the $5 \%$ level

* $=$ significant at the $10 \%$ level

$+=$ No result recorded. Cell frequency too low. 
Appendix A: Extract from the final level summary of the manual coding process: an analysis of responses to paragraph 17 of Exposure Draft 7 Financial Instruments: Disclosures - accepted and rejected outcome-oriented comments

\begin{tabular}{|c|c|c|c|c|c|c|}
\hline $\begin{array}{l}\text { Paragraph } \\
\text { number } \\
\text { (ED 7) }\end{array}$ & $\begin{array}{l}\text { Scope of } \\
\text { requirement(s) }\end{array}$ & $\begin{array}{l}\text { Section / } \\
\text { Requirement }\end{array}$ & $\begin{array}{l}\text { Accepted } \\
\text { changes: details }\end{array}$ & $\begin{array}{l}\text { Minor, } \\
\text { Moderate, } \\
\text { or Major } \\
\text { Change? }\end{array}$ & $\begin{array}{l}\text { Constituent who } \\
\text { proposed change? }\end{array}$ & $\begin{array}{l}\text { Were these } \\
\text { changes } \\
\text { discussed? }\end{array}$ \\
\hline Para 17 & $\begin{array}{l}\text { Significance of } \\
\text { Financial } \\
\text { Instruments for } \\
\text { Financial } \\
\text { Position and } \\
\text { Performance }\end{array}$ & $\begin{array}{l}\text { Definition } \\
\text { clarification }\end{array}$ & $\begin{array}{l}\text { Clarification of } \\
\text { the allowance } \\
\text { account } \\
\text { definition }\end{array}$ & Moderate & $\begin{array}{l}\text { CL10 German } \\
\text { Accounting } \\
\text { Standards } \\
\text { Committee } \\
\text { CL21 Deloitte } \\
\text { Touche Tohmatsu } \\
\text { International } \\
\text { CL25 Japanese } \\
\text { Bankers Association } \\
\text { CL32 South African } \\
\text { Institute of } \\
\text { Chartered } \\
\text { Accountants } \\
\text { CL49 Conseil } \\
\text { National de la } \\
\text { Comptabilité (CNC) } \\
\text { CL78 Institute of } \\
\text { Chartered } \\
\text { Accountants of New } \\
\text { Zealand } \\
\text { CL104 European } \\
\text { Financial Reporting } \\
\text { Advisory Group } \\
\text { (EFRAG) }\end{array}$ & Yes \\
\hline $\begin{array}{l}\text { Paragraph } \\
\text { number } \\
\text { (ED 7) }\end{array}$ & $\begin{array}{l}\text { Scope of } \\
\text { requirement(s) }\end{array}$ & $\begin{array}{l}\text { Section / } \\
\text { Requirement }\end{array}$ & $\begin{array}{l}\text { Rejected } \\
\text { changes: details }\end{array}$ & $\begin{array}{l}\text { Minor, } \\
\text { Moderate, } \\
\text { or Major } \\
\text { Change? }\end{array}$ & $\begin{array}{l}\text { Constituent who } \\
\text { proposed change? }\end{array}$ & $\begin{array}{l}\text { Were these } \\
\text { changes } \\
\text { discussed? }\end{array}$ \\
\hline Para 17 & $\begin{array}{l}\text { Significance of } \\
\text { Financial } \\
\text { Instruments for } \\
\text { Financial } \\
\text { Position and } \\
\text { Performance }\end{array}$ & $\begin{array}{l}\text { Definition } \\
\text { clarification / } \\
\text { amendment }\end{array}$ & $\begin{array}{l}\text { Modification of } \\
\text { the allowance } \\
\text { account } \\
\text { definition and } \\
\text { disclosure } \\
\text { requirements }\end{array}$ & Major & $\begin{array}{l}\text { CL15 Raad voor de } \\
\text { Jaarverslaggeving } \\
\text { (Council for Annual } \\
\text { Reporting) } \\
\text { CL17 Syngenta } \\
\text { International AG } \\
\text { CL78 Institute of } \\
\text { Chartered } \\
\text { Accountants of New } \\
\text { Zealand }\end{array}$ & $\begin{array}{l}\text { Yes } \\
\text { No }\end{array}$ \\
\hline
\end{tabular}

